\title{
Quebra do segredo profissional por padres católicos: (im)possibilidade de violação do sigilo sacramental
}

\author{
Breach of professional secret by catholic priests: \\ (im)possibility of violation of sacramental secrecy
}

Samyle Regina Matos Oliveira ${ }^{1}$

Universidade Federal da Bahia - Salvador/BA, Brasil

samyle.adv@gmail.com

http://lattes.cnpq.br/2546676196350505

http://orcid.org/0000-0002-0221-7719

\section{Thyerrí José Cruz Silva ${ }^{2}$}

Universidade Tiradentes - Aracaju/SE, Brasil thyerricruzdireito@outlook.com

http://lattes.cnpq.br/6987132345466967

https://orcid.org/0000-0001-7250-0790

\section{Luiz Fernando Kazmierczak ${ }^{3}$}

Universidade Estadual do Norte do Paraná - Jacarezinho/PR, Brasil

lfkaz@uenp.edu.br

http://lattes.cnpq.br/7437009978505769

https://orcid.org/0000-0003-0653-6255

1 Doutoranda em Direito pela UFBA. Coordenadora do curso de Direito da Universidade Tiradentes, campus Propriá-SE. Advogada. Professora das disciplinas de Direito Penal e Direito Internacional. Mestre em Ciência Jurídica pelo Programa de Pós-graduação da Universidade Estadual do Norte do Paraná.

2 Graduando em Direito pela Universidade Tiradentes.

3 Doutor em Direito Penal pela Pontifícia Universidade Católica de São Paulo (PUC/ SP), Mestre em Ciência Jurídica pela Universidade Estadual do Norte do Paraná (UENP) e Graduado em Direito pela Universidade Estadual do Norte do Paraná (UENP) na Faculdade Estadual de Direito do Norte Pioneiro (2004). Atualmente é professor adjunto da Universidade Estadual do Norte do Paraná (UENP), na graduação e pós-graduação em Ciência Jurídica (Mestrado). 
Resumo: O sigilo sacramental suscita grandes discussões acerca da violação do segredo profissional, conduta tipificada pelo art. 154 do Código Penal brasileiro, em decorrência do caráter absoluto da sua inviolabilidade, para a doutrina católica, e das hipóteses de justificação, exceções elaboradas pela doutrina penal pátria. Este artigo tem como finalidade principal analisar a inviolabilidade do sigilo sacramental, e se esta natureza persiste, mesmo com a incidência de uma excludente de ilicitude ou consentimento do penitente. A metodologia empreendida, realizada a partir de um levantamento bibliográfico que considerou tanto normas católicas e jurídicas, quanto a doutrina penal pátria permitiu identificar que o dever de resguardar segredo profissional é absoluto, no caso dos padres confessores, independentemente do conteúdo da confissão proferida pelo penitente ou de sua anuência para a relevação, pois esses devem obediência ao direito leigo e ao direito canônico, que, em seus dispositivos, estabelecem garantias normativas tanto ao livre exercício do ministério religioso, quanto à liberdade e intimidade do confidente no ato de expor seus pecados isento de eventuais punições pelas informações passadas via confissão.

Palavras-Chave: Confissão católica; Ilicitude; Intimidade; Violação.

ABSTRACT: Sacramental secrecy raises major discussions about the violation of professional secrecy, a conduct typified by art. 154 of the Brazilian Penal Code, due to the absolute character of its inviolability, for catholic doctrine, and the hypothesis of justification, exceptions elaborated by the Brazilian criminal doctrine. The main purpose of this article is to analyze the inviolability of sacramental secrecy, and whether this nature persists, even with the incidence of an exclusion of illegality or consent from the penitent. The methodology undertaken, based on a bibliographic survey that considered both catholic and legal norms, as well as the Brazilian criminal doctrine, allowed to identify that the duty to protect professional secrecy is absolute, in the case of confessors priests, regardless of the content of the confession given by the penitent or their consent to the reveal, as they owe obedience to lay and canon law, which, in their provisions, establish normative guarantees both to the free exercise of religious ministry, and to the freedom and intimacy of the confidant in the act of exposing their sins exempt from any punishment for information given via confession.

KeYwords: Catholic confession; Illicitness; Intimacy; Violation. 
SUMÁRIO: Introdução; 1. Breves comentários sobre relações entre direito e religião; 2. A confissão e o sigilo sacramental; $2.1 \mathrm{O}$ sigilo sacramental para a doutrina católica; 2.2 Sigilo sacramental e ordenamento jurídico brasileiro; 3. Violação do sigilo sacramental e do segredo profissional: (im)possibilidade?; Considerações finais; Referências..

\section{INTRODUÇÃO}

O presente estudo tem como finalidade principal analisar a inviolabilidade do sigilo sacramental e, consequentemente, do segredo profissional por parte dos padres católicos, e se esta inviolabilidade persiste, mesmo com a incidência de uma justa causa, considerando-se, para atingir este escopo, aspectos da doutrina pátria, das normas católicas e brasileiras acerca do dever de guardar o segredo profissional.

Despontam como objetivos específicos do trabalho: expressar a relação entre Direito e a religião católica; demonstrar a relevância da confissão sacramental para os ordenamentos católico e jurídico; discutir o caráter absoluto da inviolabilidade do segredo profissional por parte dos padres católicos.

Sendo esta inviolabilidade uma problemática significativa dentro da relação entre o Direito e a religião católica, o artigo traz como problema o seguinte questionamento: o segredo profissional obtido pelo padre através da confissão, permanece inviolável, independentemente da alegação de justa causa, como excludente de ilicitude ou consentimento do penitente?

Para tanto, utiliza-se uma pesquisa documental e bibliográfica, principalmente nos ramos do Direito Canônico - para compreender a ótica católica do sigilo sacramental - e Direito Penal - com fulcro na violação de segredo profissional -, contando, ainda, com uma menção ao Direito Constitucional - quanto ao direito personalíssimo à intimidade - e à legislação processual, no tocante a impedimentos de partes e testemunhas que são resguardadas pela condição especial ministerial.

Assim, a metodologia empreendida neste trabalho pretende demonstrar que, apesar de se aduzir a possibilidade de violação do sigilo 
sacramental, em caso de justa causa, o dever de resguardá-lo permanece para o sacerdote católico, a partir do falseamento das hipóteses de justa causa que elidem o dever de sigilo trazidas pela doutrina e pelas exceções criadas pelo art. 154 do Código Penal e art. 207 do Código de Processo Penal, confrontadas por normas católicas e pelo art. 13 do Decreto 7.107/2010.

Este trabalho científico é relevante para tentar suprir lacunas interpretativas e dissertativas referentes ao sigilo sacramental e o dever de seu resguarde, haja vista os conflitos de deveres impostos pelo ordenamento jurídico que decorrem de seu caráter, entendido como absoluto pelo ordenamento católico, em que pese as normas brasileiras, como dito, conterem certas exceções.

O trabalho está dividido em três partes principais, sendo a primeira um compilado de breves comentários sobre as relações entre Direito e a religião católica; a segunda, uma análise sobre a confissão sacramental e seu sigilo, tanto na ótica católica quanto para o ordenamento jurídico brasileiro; e, por fim, a discussão sobre a (im)possibilidade de sua violação, independentemente do bem jurídico contraposto ou do consentimento do penitente.

\section{Breves comentários sobre relações entre Direito e a RELIGIÃo CATÓLICA}

Por muito tempo, a religião católica, exerceu domínio absoluto sobre as realidades humanas. As crenças formulavam as explicações necessárias e até o Direito era considerado como uma manifestação da vontade divina, pois, nesse período, a classe sacerdotal exercia o monopólio do conhecimento jurídico, sob o pálio de que, em seus oráculos, recebiam de Deus as leis e os códigos (NADER, 2016, p. 33).

Dentre os pontos em comum entre Direito e o catolicismo, um deles diz respeito ao bem e sua vivência, pois a justiça, finalidade máxima do Direito, integra a noção do bem, almejado também pela aludida denominação religiosa ${ }^{4}$. Todavia, esta analisa a justiça em um campo mais

4 Cân 1807. "A justiça é a virtude moral que consiste na constante e firme vontade de dar a Deus e ao próximo o que lhes é devido." (JOÃO PAULO II, 1992, s.p.). 
amplo, que envolve os deveres dos homens também para com Deus, e não apenas ao seu semelhante (NADER, 2016, p. 34).

Um outro aspecto da relação entre a religião católica - agora no caso da confissão católica - e o Direito refere-se ao fato de o dito sacramento parecer com um julgamento, dado que "na confissão sacramental, o juiz é o apóstolo ou seu legítimo sucessor no ministério sacerdotal" e "a sentença final, a ratificar-se no céu, é proferida pelo juiz ${ }^{5}$, consoante as disposições morais do penitente" (DESTÉFANI, 1941, p. 27).

Noutro sentido, "a penitência que o confessor impõe deve ter em conta a situação pessoal do penitente e procurar o seu bem espiritual. Deve corresponder, quando possível, à gravidade e natureza dos pecados cometidos", podendo consistir em orações, donativos, obras de misericórdia, serviço ao próximo, privações voluntárias e sacrifícios (Cân. 1460, Catecismo da Igreja Católica) (JOÃO PAULO II, 1992), resguardando semelhanças com a individualização e dosimetria da pena, que variam de acordo com a gravidade do delito cometido.

Nesse aspecto, uma diferença significativa entre Direito Penal e a religião católica, esta em sua vertente normativa, reside nas penas aplicadas pelo primeiro e pelo Direito Canônico, uma vez que o ius puniendi estatal mantém em seu leque as penas privativas de liberdade, de restrição de direitos e de caráter pecuniário; já o ordenamento jurídico católico considera, basicamente, as penas espirituais - como excomunhão e penitência -, com o escopo de levar o agente ao arrependimento e correção (PRADO; CARVALHO; CARVALHO, 2014, p. 83).

\section{A confissão e o sigilo sacramental}

A confissão, no âmbito católico, acontece quando os fiéis se arrependem de terem cometidos pecados e os confessam, com o propósito

5 “Cân. 1465. Ao celebrar o sacramento da Penitência, o sacerdote exerce o ministério [...] do justo juiz que não faz acepção de pessoas e cujo juízo é, ao mesmo tempo, justo e misericordioso. Em resumo, o sacerdote é sinal e instrumento do amor misericordioso de Deus para com o pecador." (JOÃO PAULO II, 1992, s.p.). 
de se emendarem, mediante a absolvição conferida pelo ministro legítimo, alcançando, assim, Deus e o perdão dos pecados cometidos após o batismo, nos termos do cân. 959 do Código de Direito Canônico (JOÃO PAULO II, 1983, p. 173).

Conforme a Bíblia, a origem da confissão deu-se quando Jesus conferiu aos apóstolos e seus legítimos sucessores a prerrogativa de perdoar os pecados, a partir do Evangelho segundo João, capítulo 20, versículo 22: "Recebei o Espírito Santo. A quem perdoardes os pecados, ser-lhes-ão perdoados. A quem retiverdes os pecados, ser-lhes-ão retidos" (DESTÉFANI, 1940, p. 18).

Assim, segundo preleciona a doutrina católica, não sendo de origem humana, e sim divina, a confissão sacramental produz efeitos espirituais na alma, com o escopo de salvá-la e santificá-la. Estes efeitos dizem respeito à infusão da graça santificante do perdão em uma alma que dele estava privada, remissão da pena eterna, revivescimento de boas obras praticadas antes dos pecados mortais, sossego à consciência martirizada pelo remorso, e também autoconhecimento (DESTÉFANI, 1940, pp. 18-21 e 44).

Ainda dentro da seara religiosa, muito se questiona a respeito da figura do confessor na consecução do aludido sacramento ${ }^{6}$, dado que, se apenas Deus perdoa os pecados, conforme a Bíblia, seria prescindível a presença do padre confessor - considerado, pelo Direito, como "confidente necessário" -, uma vez que este é um ser humano, e pecador, tal qual o confidente.

6 Este artigo não visa defender ou questionar a legitimidade do confidente necessário em seu aspecto religioso, e sim analisá-lo como figura albergada pelo Art. 154 do Código Penal, dada a pertinência do tema para o Direito.

7 Diferentemente do conceito em âmbito religioso, em que o padre recebe a terminação de "confessor", a terminologia “confidentes necessários”, adotada pelo Direito Penal, baseia-se na essência de determinadas atividades, em que a relação profissional-cliente possui especificidades, encerrando confidências, sigilos e segredos cuja revelação indevida viola, no mínimo, a ética profissional. Assim, a designação de confidentes necessários no âmbito jurídico diz respeito à tomada de conta de fatos particulares de vidas alheias, como ocorre com o médico, o psicólogo e o sacerdote (BITENCOURT, 2018a, p. 550; JESUS, 2014, p. 339-340). 
Contudo, a dogmática católica esclarece que "na sua infinita sabedoria, Deus achou conveniente perdoar, por via normal, através da sentença autorizada de outros homens", por ser o meio ordinário escolhido por Ele para instruir e santificar os indivíduos ${ }^{8}$, bem como a necessidade que o ser humano tem de ouvir uma palavra concreta que o assegure do perdão realmente conseguido9 (DESTÉFANI, 1940, p. 28).

Não se duvida, portanto, segundo o Cristianismo, que o perdão, de fato, vem de Deus. Todavia, Jesus confiou também à Igreja a administração deste sacramento, pelo fato de o padre ser, para a religião católica, representante dele, cabendo-lhe, pois, acolher o penitente e perdoar seus pecados, pela autorização divina decorrente da sucessão apostólica ${ }^{10}$ (DUARTE, 2008, p. 6).

Outrossim, segundo os mesmos ensinamentos cristãos, é consabido que Deus conhece o íntimo de cada indivíduo, mas o confessor não. Por isso, há a necessidade de o penitente contar seus pecados ao ministro do sacramento, uma vez que este não tem o condão de adivinhar os pecados ou de perdoá-los sem ouvi-los, já que, se isto fosse possível, o pecador não estaria cumprindo com o principal motivo que origina a confissão: o arrependimento dos pecados cometidos.

Deste modo, quando o pecador busca a confissão sacramental, almeja a tranquilidade de sua consciência, pela certeza de que Deus lhe perdoou pelas faltas por intermédio de seu ministro, o confessor, encontrando neste um estímulo para prosseguir no caminho reto (DESTÉFANI, 1940, p. 42).

8 “Cân. 1441. Só Deus perdoa os pecados. Jesus, porque é Filho de Deus, diz de Si próprio: «O Filho do Homem tem na terra o poder de perdoar os pecados» (Mc 2, 10) e exerce este poder divino. [...] Mais ainda: em virtude da sua autoridade divina, concede este poder aos homens para que o exerçam em seu nome." (JOÃO PAULO II, 1992, s.p.).

9 “Cân. 960. A confissão individual e íntegra e a absolvição constituem o único modo ordinário pelo qual o fiel, consciente de pecado grave, se reconcilia com Deus e com a Igreja" (JOÃO PAULO II, 1983, p. 171).

10 "Cân. 1461. Uma vez que Cristo confiou aos Apóstolos o ministério da reconciliação os bispos, seus sucessores, e os presbíteros, colaboradores dos bispos, continuam a exercer tal ministério. Com efeito, os bispos e os presbíteros é que têm, em virtude do sacramento da Ordem, o poder de perdoar todos os pecados" (JOÃO PAULO II, 1992, s.p.). 


\subsection{O SIGILO SACRAMENTAL PARA A DOUTRINA CATÓLICA}

A doutrina católica, em sentido jurídico, é regida pelo Código de Direito Canônico, “compilação do que há de mais antigo na Igreja Católica, ou seja, é considerado uma herança histórica”, um ordenamento de leis baseadas nos sentimentos deixados por Jesus e encontrados nas escrituras bíblicas (MORALES, 2018, p. 14).

Conforme Prado, Carvalho e Carvalho (2014, p. 82), a denominação ‘canônico’ advém de kânon, que significa "regra”, "norma”, termos que em outrora diziam respeito às normas de cunho religioso. Segundo Maciel (2007, s.p.), "o direito canônico ganha força porque a Igreja também possui um corpo social”, necessitando, portanto, de normas que estabeleçam sua estrutura hierárquica e orgânica, definindo, ainda, direitos e deveres de seus fiéis.

Dentre as contribuições do Direito Canônico para o Direito leigo podem ser destacadas: a contribuição para a humanização das penas, o fortalecimento do Direito Penal enquanto público; e a afirmação da igualdade de todos os homens, embora, nesse caso, ainda fosse perante Deus, e não perante a lei (PRADO; CARVALHO; CARVALHO, 2014, p. 83).

Quanto ao sacramento da confissão, a partir do momento que o penitente procura o confessor para contar-lhe os pecados e buscar o perdão divino, é necessário ser tomado como basilar o princípio de inviolabilidade do sigilo sacramental, que, para o padre, torna-se um dever o seu resguarde, dada a dimensão da responsabilidade de perdoar os pecados, conferida ao seu ministério sacerdotal ${ }^{11}$.

Isso se dá porque as informações que o confessor ouve no confessionário decorrem do seu mister de representante de Deus. Ou seja, os conhecimentos obtidos na confissão não são tomados, de forma alguma, como ciência humana e comunicável. Por essa razão, o sacerdote deve

11 Os fatos protegidos pelo sigilo se referem ao diálogo íntimo e de caráter confidencial, características que surgem quando o titular do segredo lhe atribui secretismo (AZEVEDO, 2015, p. 61). Assim, deve-se distinguir o que é sacramental e o que é situacional dentro da confissão, pois as informações sem relação com os pecados cometidos podem não ser abrangidas pelo sigilo (LOPES, 2006, p. 59). 
comportar-se como se não tivesse tomado conhecimento de coisa alguma, para não violar o sigilo (LOPES, 2006, p. 52).

Nesta senda, o Código de Direito Canônico estabelece, no Cânone 983, § $1^{\circ}$, que "o sigilo sacramental é inviolável; pelo que o confessor não pode denunciar o penitente nem por palavras nem por qualquer outro modo nem por causa alguma" (JOÃO PAULO II, 1983, p. 175).

Conforme o Cân. 1467 do Catecismo da Igreja Católica, "a igreja declara que todo o sacerdote que ouve confissões está obrigado a guardar segredo absoluto sobre os pecados que os seus penitentes lhe confessam, sob penas severíssimas", tampouco podendo "servir-se dos conhecimentos que a confissão lhe proporciona sobre a vida dos penitentes" (JOÃO PAULO II, 1992, s.p.).

Dentre as penas severíssimas, está a excomunhão, sanção aplicada para o confessor que transgride o segredo da confissão, conforme o Cân. 1388, § $1^{\text {o: }}$ "o confessor que violar directamente o sigilo sacramental, incorre em excomunhão latae sententiae, reservada à Sé Apostólica; o que o violar apenas indirectamente seja punido segundo a gravidade do delito" (JOÃO PAULO II, 1983, p. 241).

Desta forma, a previsão de consequências para a infração de violar o segredo da confissão, além de impedir rupturas sociais - uma vez que a transmissão de fatos e conhecimentos obtidos através da confissão levaria à perda de confiança nas profissões que tem como primazia o sigilo (CESCA; ORZARI, 2016, p. 558; CAPEZ, 2017, p. 417; PRADO, 2008, p. 315; BITENCOURT, 2018a, pp. 550 e 552) -, obsta, também, que se transgrida a inviolabilidade do referido sacramento, contido na norma jurídica da Igreja Católica, instituído, segundo a aludida denominação religiosa, pelo próprio Jesus.

Assim, do prisma religioso, a violação do sigilo sacramental desrespeita: (i) a confidencialidade própria do sacramento da confissão; (ii) a confiança que o penitente tem no confessor e na garantia de inviolabilidade do conhecimento dos pecados; (iii) o disposto no Código de Direito Canônico e no Catecismo da Igreja Católica; e (iv) os ensinamentos de Jesus, que, segundo a tradição cristã católica, instituiu a confissão e passou para seus discípulos e seguintes, através da sucessão apostólica.

Nesse aspecto, as punições e sanções da doutrina católica para a violação de segredo confessional são entendidas como "uma consequência 
unilateral da ação praticada pelo excomungado, ou seja, a excomunhão é automática se houve orientação da igreja a respeito da prática de determinada conduta (pecado) e mesmo assim o indivíduo a comete" (MORALES, 2018, p. 20).

Dessa forma, observa-se que as normas de caráter penal aplicadas pelo Direito Canônico não visam à privação de liberdade ou de direitos, mas simplesmente a uma expiação espiritual como forma de autoconhecimento e busca por uma vida reta e livre dos pecados.

Todavia, diferentemente destas penas de âmbito canônico, alguns ordenamentos jurídicos punem com sanções de caráter penal a violação do segredo profissional, o que abrange o sigilo sacramental. Isso se dá porque as relações sociais, via de regra, são regulamentadas pela ordem jurídica, moral e religiosa, as quais mantêm princípios intrínsecos e, muitas vezes, coincidentes. Assim, nesse sentido, a inviolabilidade do sigilo sacramental seria uma norma de natureza religiosa, acolhida pelo legislador - ordem jurídica -, visando resguardar a moral do penitente e do confessor em razão da necessária harmonia social (AZEVEDO, 2015, p. 64-65), que restaria fragilizada se as violações de sigilo sacramental fossem permitidas pelas leis.

\subsection{SIGILO SACRAMENTAL E ORDENAMENTO JURÍDICO BRASILEIRO}

Com a passagem do Direito Natural para o Direito Positivo, e com a redução progressiva da intervenção religiosa nos assuntos próprios do Estado, fez-se necessário estabelecer medidas que, no ordenamento jurídico laico, preservassem os objetos de ordem religiosa. No caso desse artigo, os compreendidos dentro do âmbito do sacramento da confissão, como o sigilo sacramental e segredo profissional, deveres de o padre confessor manter absoluta a inviolabilidade acerca dos fatos que teve conhecimento por meio da confissão, independentemente de estes constituírem realidades a serem apreciadas judicialmente.

A proteção do Estado ao sigilo sacramental justifica-se pelo fato de que sua ausência impediria a liberdade religiosa dos professantes do catolicismo, adeptos da confissão, os quais não sentiriam liberdade para confessar seus pecados, não se tratando, pois de "uma questão de defesa 
dos dogmas ou da doutrina da Igreja Católica" (LOPES, 2006, p. 93), e sim pelo fato de o segredo relatado ao sacerdote atingir "a dimensão mais subjectiva do ser humano", referindo-se "àquilo que vai na alma de cada um". Assim, quem recorre ao padre para expiar seus pecados, faz isso com a certeza de que o que é revelado fica preservado para sempre (AZEVEDO, 2015, p. 70).

No Brasil, Estado Democrático de Direito, a Constituição consagra como direito fundamental a inviolabilidade da intimidade, da vida privada, da honra e da imagem das pessoas (art. $5^{\circ}, \mathrm{X}, \mathrm{CF} / 88$ ). Estes elementos formam o rol dos ditos direitos personalíssimos, considerados indisponíveis, inalienáveis, intransmissíveis, irrenunciáveis, ilimitados e imprescritíveis.

Nesse sentido, sem a pretensão de exaurir a discussão sobre os direitos de personalidade, tem-se que privacidade "engloba os níveis de relacionamento social que o indivíduo habitualmente mantém oculto do público em geral, dentre eles: a vida familiar, as aventuras amorosas, o lazer, o segredo dos negócios" etc. Já a intimidade ${ }^{12}$ vai além, "justamente para representar o espaço que o sujeito deseja manter impenetrável mesmo aos mais próximos" (FERRAZ, 2006, p. 85).

Concordante, Marcelo Novelino (2016, p. 337) aduz que "a intimidade está relacionada ao modo de ser de cada pessoa, ao mundo intrapsíquico aliado aos sentimentos identitários próprios" e "compreende os segredos e as informações confidenciais”, características também encontradas na confissão sacramental.

Nessa discussão, "conquanto não figure expressamente o rol de direitos fundamentais", pode-se inferir que o dever de guardar sigilo profissional e não violar o segredo vela pelo respeito ao direito de intimidade do confidente (BARROS, 1996, p. 19), visto que "o bom desempenhar da profissão e o cumprimento de suas finalidades dentro da sociedade exigem, necessariamente, a discussão sobre fatos e informações que se

12 Dirley da Cunha Júnior atribui ao direito à intimidade o título de "direito especial ligado à essência do indivíduo". E continua o autor: "a intimidade é a vida secreta ou exclusiva que alguém reserva para si, sem nenhuma repercussão social, nem mesmo junto à sua família, aos seus amigos e ao seu trabalho. [...] É, em suma, o direito de proteção dos segredos mais recônditos do indivíduo" (CUNHA JÚNIOR, 2014, p. 555). 
inserem na esfera mais reservada do indivíduo" (CESCA; ORZARI, 2016, p. 557). Assim, consagra-se o tripé confissão-intimidade-sigilo, que tem caráter sagrado desde a Antiguidade, quando a violação de segredo significava "uma transgressão aos preceitos de natureza religiosa" (PRADO, 2008, p. 314).

O ordenamento jurídico brasileiro passou a considerar a violação de segredo como infração penal a partir as Ordenações Filipinas, embora essas protegessem "tão somente os segredos da casa real, nada dispondo sobre a violação de segredos privados." O Código Criminal de 1830 punia a revelação de segredo por parte de funcionário. O codex sucessor, de 1890, tipificou o crime de violação do segredo profissional, hoje, art. 154 do Código Penal de 1940 (PRADO, 2008, p. 315).

Assim, estabelece o art. 154 do Código Penal brasileiro que constitui crime "revelar alguém, sem justa causa, segredo, de que tem ciência em razão de função, ministério, ofício ou profissão, e cuja revelação possa produzir dano a outrem”. Segundo Bitencourt (2018a, p. 551), “a conduta tipificada é revelar, que significa contar a alguém segredo profissional. Revelar tem abrangência mais restrita do que divulgar: aqui implica um número determinado de pessoas; lá é suficiente alguém.”

Conforme Guilherme Nucci (2017), o termo ministério engloba o padre, pois "ministério é o exercício de uma atividade religiosa". Ademais, "é próprio do sacerdote ouvir a confissão de fiéis, devendo guardar segredo. A revelação do que lhe foi contado pode constituir crime" (NUCCI, 2017, p. 940).

O crime em questão objetiva tutelar a liberdade individual, sobretudo a esfera dos segredos, "que deve ser resguardada da indiscrição alheia” (PRADO, 2008, p. 315). Outrossim, o tipo é especial próprio quanto ao sujeito ${ }^{13}$, pois apenas pode ser cometido por quem ostente a qualidade decorrente da função, ministério, ofício ou profissão, e que mantenha "um especial vínculo de confiança com o sujeito passivo" (PRADO, 2008, p. 316). Assim, quando essa confiança é quebrada, "abre-se a possibilidade

13 “Trata-se de uma modalidade muito peculiar de crime próprio, uma vez que a condição especial não se encontra no sujeito ativo, mas na natureza da atividade, que lhe possibilita ter ciência do segredo profissional" (BITENCOURT, 2018a, p. 550). 
de se responsabilizar criminalmente aquele que não cumpriu com os seus deveres de fidelidade e lealdade" (GRECO, 2009, p. 603).

A revelação pode ser total ou parcial, assim como realizada através de múltiplas formas de execução, "seja oral, escrita, gestos, fotografias, desenhos, imagens etc.”, devendo, ainda, ter por objeto o segredo, "informe cuja revelação possa produzir dano para o seu titular" quando divulgado ${ }^{14}$. Nessa perspectiva, "não são todos os dados sigilosos da vítima albergados pela proteção jurídico-penal, mas tão somente aqueles que, além de objetivamente relevantes, se encontrem vinculados à atividade profissional desempenhada pelo sujeito ativo" (PRADO, 2008, p. 317318), nexo causal do crime (JESUS, 2014, p. 340) ${ }^{15}$.

A importância dada pelo ordenamento jurídico brasileiro ao segredo profissional é tamanha, que, além da tipificação para sua violação, no direito material, o Código de Processo Civil e o Código de Processo Penal estabelecem dispositivos que impedem sua violação no que diz respeito ao campo processual, mais especificamente às partes e testemunhas: a) "Art. 388. A parte não é obrigada a depor sobre fatos: [...] II - a cujo respeito, por estado ou profissão, deva guardar sigilo"; b) "Art. 448. A testemunha não é obrigada a depor sobre fatos: [...] II - a cujo

14 No caso da confissão sacramental, "a violação é directa quando quem viola o sigilo ou o segredo revela pecado e pecador, não importando que este seja designado pelo seu nome próprio ou por outros dados ou factos que só a ele dizem respeito. [...] A violação é indirecta ou mediata quando, sem designar concretamente a pessoa que cometeu o pecado, o confessor revela tais detalhes que pode presumir-se quem foi o pecador." (LOPES, 2006, p. 60).

15 Em 2010, o Ministério Público do Rio de Janeiro denunciou o padre Marcus Vinicius Antunes da Trindade por violação de segredo profissional (art. 154, $\mathrm{CP})$. No caso, o réu teria revelado a Beatriz Silva de Araújo informações obtidas na confissão de seu namorado, Frank Omenuco Omenka, causando danos no relacionamento dos dois. As tentativas de conciliação não foram aceitas, e o padre seguiu relutante e confiante em sua inocência, segundo seu advogado. Em 23/04/2012, a juíza Priscila Abreu David, mencionando a relação entre a confissão católica e o direito constitucional à intimidade - como feito neste artigo -, assentou que os depoimentos das testemunhas pouco esclareciam sobre os fatos, decidindo, por fim, pela absolvição do padre Marcus Vinicius, em razão do princípio in dubio pro reo, vez que as provas eram escassas e contraditórias. $\mathrm{O}$ Ministério Público recorreu, mas o processo foi arquivado em 26/02/2014. (18 Juizado Especial Criminal - Regional de Campo Grande. Processo $n^{\circ} 0005735$ 30.2010.8.19.0205. Disponível em: < https://bit.ly/2xVOIHQ >.). 
respeito, por estado ou profissão, deva guardar sigilo"16; e c) "Art. 207. São proibidas de depor as pessoas que, em razão de função, ministério, ofício ou profissão, devam guardar segredo, salvo se, desobrigadas pela parte interessada, quiserem dar o seu testemunho". ${ }^{17}$

Chama atenção, pois, a parte final do art. 207 do CPP, que excepciona o dever de não depor em caso de permissão da parte interessada, isto é, no caso da confissão católica, o consentimento do penitente. Em que pese o fato de esta discussão ser trabalhada com maior minuciosidade no tópico seguinte, cabe, de início, salientar que o Brasil assinou, junto à Santa Sé, um tratado internacional - Concordata 2008 (Decreto $\left.n^{\circ} 7.107 / 2010\right)$ - que traz importantes observações, como o art. 13, segundo o qual "é garantido o segredo do ofício sacerdotal, especialmente o da confissão sacramental", o que contrasta com o referido dispositivo do Código de Processo Penal, demonstrando um conflito entre normas.

De toda forma, em razão dessa norma, a faculdade trazida pela parte final do art. 207 do Código de Processo Penal converte-se em uma vedação, dada a existência de um tratado internacional internalizado neste sentido.

Noutro sentido, o Código de Processo Penal se refere à proibição do dever de depor, não apenas da dispensa, como ocorre no Código de Processo Civil (PACELLI, 2018, p. 420). Para Barros (1996, p. 22), a diferenciação consiste no fato de que

no campo processual civil, a lei lhes institui um direito de silêncio, facultando ao depoente requerer ao juiz que o escuse de depor

16 Estas duas primeiras hipóteses mencionadas citam a locução "por estado ou profissão". Com “estado", nesse caso, deve-se entender como exemplo um líder religioso. Ademais, a responsabilização criminal da infração destes dispositivos não prejudica eventuais consequências cíveis (NEVES, 2018, p. 793), cabendo pleitear indenização por perdas e danos, a depender do caso.

17 Diferentemente do Código de Processo Penal brasileiro, o item 1 do art. $135^{\circ}$ do Código de Processo Penal Português dispõe que "os ministros de religião ou confissão religiosa e os advogados, médicos, jornalistas, membros de instituições de crédito e as demais pessoas a quem a lei permitir ou impuser que guardem segredo podem escusar-se a depor sobre os factos por ele abrangidos." O item 5 do mesmo dispositivo também impede que o segredo religioso seja violado, independentemente da justificativa, conforme os itens 3 e 4 do mesmo artigo. 
[...]. No processo penal, onde os valores postos em julgamento são de altíssima relevância, haja vista a possibilidade de envolver a liberdade individual de uma ou mais pessoas, a lei impõe à testemunha o dever de calar.

Concordante, assevera Nucci (2012, p. 490) que "não se trata, neste caso, de mera faculdade ou direito, mas de imposição legal a determinadas pessoas que, em razão da sua qualidade, não podem prestar depoimento, nem declarações", ressaltando que "a obrigação de guardar sigilo advém de normas específicas, regulamentos, costumes estatutos etc.”. Dentro do âmbito de 'normas específicas', encontram-se as que regem a organização da Igreja Católica, como o Código de Direito Canônico.

Outrossim, a prova que lesa o direito processual é a ilegítima; já a que lesa o direito material é a ilícita (RANGEL, 2015, pp. 474 e 476). Dessa forma, o depoimento de um padre sobre fato conhecido a partir de confissão caracteriza tanto prova ilícita, quanto ilegítima - por desrespeitaram o direito processual e material -, a depender da ação em curso, levando "à nulidade processual do ato de formação da prova" (CESCA; ORZARI, 2016, p. 574).

No plano das nulidades, sabida a sua distinção em relativa referente ao interesse das partes - e absoluta - que dizem respeito "ao processo penal enquanto função jurisdicional” -, constata-se que, mesmo com a exceção criada pelo legislador no final do art. 207 do Código de Processo Penal, o depoimento do padre, apesar da anuência do penitente, restaria nulo, por violar o direito constitucional à intimidade deste, "causando reflexos irreparáveis na qualidade da jurisdição prestada" (PACELLI, 2018, p. 926-927).

Outrossim, os prejuízos decorrentes das nulidades relativas devem ser demonstrados. Já nas nulidades absolutas, pressupõe-se a existência do prejuízo, o que não significa presunção (PACELLI, 2018, p. 927), e sim que a nulidade absoluta traz em seu bojo um perigo constatável de plano, e que atinge a coletividade. No caso da violação de sigilo sacramental, os descumprimentos ao direito constitucional à intimidade do penitente, ao art. 13 do Decreto $n^{\circ} 7.107 / 2010$ e ao cân. 983, § $1^{\circ}$ do Código Canônico, compatibilizado, por assim dizer, com o ordenamento jurídico brasileiro a partir da Concordata 2008. 


\section{VIOLAÇÃO DO SIGILO SACRAMENTAL E DO SEGREDO PROFISSIONAL: (IM)POSSIBILIDADE?}

Já se afirmou, neste estudo, que certas profissões exigem o segredo profissional pela sua natureza, visando seu bom desempenho, e para o resguardo da intimidade dos indivíduos que necessitam guardar seus informes de caráter confidencial. Todavia, diferentemente do caso de médicos, psicólogos e advogados, e em que pese as respeitadas opiniões contrárias, o sigilo sacramental reveste-se de caráter absoluto.

Em Portugal, essa inviolabilidade absoluta decorre da opção do legislador, que excepcionou ao isentar os ministros de culto de relevar o segredo profissional quando necessário para o trabalho da justiça (ALMEIDA, 2015, p. 63). O mesmo ocorreu no Brasil, como dito, nos arts. 388 e 448 do Código de Processo Civil, e o art. 207 do Código de Processo Penal, embora, como demonstrado anteriormente, a dicção do Código Penal Português tenha sido mais detalhada, e haja, no dispositivo processual penal pátrio, uma exceção, referente ao consentimento da parte interessada.

Nesse sentido, as discussões mais recentes no Brasil sobre os direitos fundamentais e constitucionais costumam salientar que no ordenamento jurídico pátrio não há um direito fundamental absoluto, posto que, em caso de conflito entre direitos, que possuem mesma hierarquia, um deverá prevalecer sobre o outro. Outrossim, em caráter penal, muito tem se dissertado acerca do consentimento do ofendido como causa supralegal de exclusão de ilicitude.

Em alusão à legislação portuguesa, que, expressamente estabelece o consentimento do ofendido como causa de exclusão de ilicitude (art. 38, Código Penal Português), Lopes assenta que o penitente pode autorizar a revelação do sigilo e do segredo, assentando que este é um direito disponível, de modo que "pode o penitente dispor dele e renunciar ao seu direito ou ao seu uso" (LOPES, 2006, p. 61).

Outrossim, Lopes (2006, p. 106-107) defende, ainda, o argumento de que o sacerdote pode revelar licitamente o sigilo sacramental quando isto se fizer necessário em casos de legítima defesa, direito de necessidade, e conflito no cumprimento de deveres jurídicos ou ordens legítimas de autoridade - figuras excludentes de ilicitudes semelhantes 
às do ordenamento jurídico brasileiro -, restando absoluto o segredo somente quando for impossível mantê-lo em sigilo" ${ }^{18}$.

De toda forma, Lopes (2006, p. 61-62), sustenta que, mesmo com a autorização e o consentimento do penitente, o confessor poderá abster-se de revelar o informe protegido pelo sigilo sacramental, visto que, mesmo com a permissão do interessado, ele não está autorizado violar o seu dever de guardar o sigilo, em razão da imposição decorrente do seu ministério sacerdotal. Assim, o consentimento do penitente gera, ao sacerdote, confidente necessário, uma faculdade de revelar o segredo, mas não uma obrigação, de modo que o ministro de culto ou confissão religiosa poderá escusar-se a prestar depoimentos como testemunha, e sua recusa não poderá levar o tribunal a ordená-lo que o faça (LOPES, 2006, p. 108).

Assim, mesmo que o consentimento do ofendido possa ser considerado como uma forma de exclusão da ilicitude e, consequentemente, uma abertura para a possibilidade de se violar o sigilo sacramental, ainda resta absoluto tal dever, para o padre confessor, que não deverá ser compelido a fazê-lo.

Noutra seara, retornando à discussão anterior, aduz-se que o segredo profissional pode ser violado sob o pálio das excludentes de ilicitude, ocasiões nas quais "o Estado admite que o particular se valha de desforço próprio para realizar a proteção de seus interesses, ainda que em detrimento da preservação do interesse de normas por ele mesmo criadas" (BUSATO, 2017, p. 448).

18 Em 2019, o Papa Francisco alterou uma norma católica que versa sobre o segredo pontifício, isto é, informes de caráter confidencial que visam manter a estrutura, a segurança e a confidencialidade das informações e pessoas envolvidas e da própria Igreja Católica enquanto instituição. Essa decisão adveio da tentativa de punir clérigos que cometem abusos sexuais ou crimes graves congêneres. Todavia, o segredo pontifício não é obtido por meio de confissão, e sim por meio de comunicações sigilosas entre destinatários determinados. Assim, a dita resolução papal não representa uma hipótese de violação de sigilo sacramental, o que não quer dizer, por outro lado, que seja menos importante. Assim, casos de crimes cometidos e confessados permanecem sob o sigilo sacramental; já as infrações ditas em segredo pontifício, podem, sim, ser relevadas para fins de punição aos responsáveis, guardadas as devidas responsabilidades com o trato desse tipo de informação para evitar escândalos e danos ainda maiores. 
Nesse aspecto, este tópico busca analisar cada uma das excludentes de ilicitude, confrontando a opinião do canonista José Joaquim Almeida Lopes e da doutrina majoritária brasileira, de que a antijuridicidade do art. 154 do Código Penal pode ser afastada, tendo como caso específico a figura do padre confessor, além de trazer novos argumentos quanto à alegação de que o consentimento do ofendido também abre uma brecha para a violação do sigilo sacramental.

Em preliminar, no caso do estado de necessidade, exige-se, objetivamente, a existência de perigo que seja inevitável, provocação involuntária do perigo e salvaguarda de direito próprio ou alheio. A regra, nessa causa de justificação, "é de que ambos os bens em conflitos estejam amparados pelo ordenamento jurídico", de modo que "esse conflito de bens é que levará, em virtude da situação em que se encontravam, à prevalência de um sobre o outro" (GRECO, 2014, p. 322).

Cabe ressaltar que "o estado de necessidade não se confunde com a legítima defesa", haja vista que na última, "a reação realiza-se contra bem jurídico pertencente ao autor da agressão injusta”, enquanto que, na primeira, "a ação dirige-se, via de regra, contra um bem jurídico pertencente a terceiro inocente.” Em suma, "no estado de necessidade há ação, na legítima defesa, reação” (BITENCOURT, 2018b, p. 420)

Dessa forma, tenha-se como exemplo o caso de um indivíduo que vai até o sacerdote e confessa que vai cometer um homicídio. Este sacerdote pode denunciar à polícia a intenção do confidente, alegando o estado de necessidade para proteger o direito à vida de terceiro? Certamente, a resposta é negativa. Primeiramente, e no sentido sacramental, porque, via de regra, não se confessa um fato ou pecado que ainda não foi cometido - salvo em caso de o penitente relevar ao padre o intuito de cometer algum pecado, o que já é um pecado, vez que, para a dogmática católica, o pecado não se restringe apenas a palavras e atos, mas também a pensamentos e até omissões ${ }^{19}$.

19 Cân. 1853. Os pecados variam conforme os critérios: "os que dizem respeito a Deus, ao próximo, à própria pessoa do pecador; pecados espirituais e carnais: ou, ainda, pecados por pensamentos, palavras, obras ou omissões.” (JOÃO PAULO II, 1992, s.p.). 
Em segundo lugar, segundo o Art. 24, CP, não se encontra, neste caso específico, o perigo inevitável, tampouco atual ${ }^{20}$ pressuposto pelo estado de necessidade, uma vez que o agente pode mudar de ideia, ou ter seu dolo frustrado por razão diversa. Em terceiro lugar, porque são impuníveis os atos preparatórios de um crime. E, por último, porque o Código

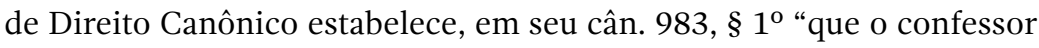
não pode denunciar o penitente nem por palavras nem por qualquer outro modo nem por causa alguma" (JOÃO PAULO II, 1983, p. 175).

Noutra hipótese, imagine-se, agora, um homicídio já cometido e que o agente confessado a conduta ao sacerdote; estaria este último habilitado ou obrigado a denunciar o crime à justiça, sob o argumento do estado de necessidade? Analisando o conteúdo literal do Art. 24 do Código Penal, não se observa, também neste caso, a existência de perigo inevitável, o que, inicialmente, aniquila a possibilidade de ser invocada a referida excludente de ilicitude. Outrossim, "a denunciação de crime não constitui justa causa para a revelação do segredo" (BITENCOURT, 2018a, p. 554).

As suposições levantadas anteriormente dizem respeito ao estado de necessidade justificante, que exclui a ilicitude. Porém, adentrando na seara da exclusão de culpabilidade, estaria o padre confessor permitido ou obrigado a violar o sigilo sacramental e o segredo profissional para denunciar um crime, alegando a inexigibilidade de conduta diversa, do estado de necessidade exculpante?

Em preliminar, a referida dirimente diz respeito à não-exigência de comportamento diverso por parte do agente (GRECO, 2014, p. 411). Todavia, para que esta seja invocada, deve haver, ao menos, um dos dois seguintes requisitos: obediência hierárquica e coação moral irresistível, de modo que nenhuma das duas é observada nos casos mencionados anteriormente - tanto de homicídio "prometido", quanto o já realizado -, não subsistindo, pois, o argumento de que o estado de necessidade

20 "Perigo passado ou futuro não pode justificar o estado de necessidade. Se o dano ou perigo já se efetivou, a ação do agente somente estará legitimada para impedir sua continuação. Se o perigo for futuro, poderá ate não se concretizar; se for passado caracterizá vingança. Em qualquer dessas hipóteses falta-lhes a característica da atualidade” (BITENCOURT, 2018b, p. 427). 
exculpante elide o fato típico de violação do segredo profissional no caso da transgressão do sigilo sacramental.

Ao revés, a inexigibilidade de conduta diversa pode despontar, juridicamente, como exemplo de objeção de consciência, ainda no campo da culpabilidade. Ou seja, tendo conhecimento de um crime, o padre confessor tem, além de um dever imposto pelas normas católicas e pelo ordenamento jurídico, a faculdade de não denunciar o crime à justiça, amparando-se na objeção de consciência, que o impede de violar o sigilo sacramental ${ }^{21}$.

A legítima defesa, outra excludente de ilicitude, estabelece como fato principal para sua argumentação a existência de uma agressão atual (presente) ou iminente (em vias de acontecer) (NUCCI, 2017, p. 294) que exija "uma reação preventiva a fim de impedir o início ou continuidade da ação", de modo que "a reação defensiva deve ser imediata; pois se for posterior não se tratará mais de justificante, mas, sim, de um ato de vingança" (SOUZA; JAPIUASSÚ, 2018, p. 199).

Utilizando-se do primeiro exemplo, seria possível que o sacerdote agisse em legítima defesa ao denunciar o desígnio homicida do indivíduo? A resposta para esta questão também é negativa, visto que "não é possível haver legítima defesa contra agressão futura [...] ou passada, que configura autêntica vingança" (NUCCI, 2017, p. 294). Este exemplo, em sentido geral, é assim explicado por Rogério Greco:

Assim, suponhamos que alguém esteja sendo vítima de uma ameaça de um mal futuro, injusto e grave [...] Poderá a vítima, no momento em que as palavras ameaçadores estão sendo proferidas, agredir o agente na defesa dessa sua liberdade pessoal? Nesse caso, especificamente, entendemos que não. Isso porque o mal prenunciado à vítima não está ocorrendo (atual) e nem prestes a acontecer (iminente), de modo que esta última tem plena possibilidade de, em

21 A respeito do que fazer nos casos de objeção de consciência, aduz Rogério Greco que, "atendendo a um critério de razoabilidade, poderá ser arguida a inexigibilidade de conduta diversa, com a finalidade de afastar a infração penal que seria atribuída ao agente", no caso do padre, uma suposta omissão em denuciar o crime à justiça, para evitar que este avilte gravemente sua consciência, cumprindo a lei a todo custo (GRECO, 2014, p. 419). 
um Estado de Direito, buscar socorro nas autoridades encarregadas da defesa da sociedade (GRECO, 2014, p. 342-343).

Ressalte-se que, nesse caso, está-se falando da cogitação, primeiro passo do iter criminis, que compreende quatro fases principais: cogitação, preparação, execução e consumação. Todavia, noutro raciocínio, caso sujeito já estivesse preparando o ato criminoso e confessasse isso ao sacerdote, seria possível a invocação da legítima defesa para a denúncia? Guilherme Nucci responde que "como regra, é inadmissível a legítima defesa contra atos preparatórios de um delito, pois não se poderia falar em atualidade ou iminência” (NUCCI, 2017, p. 294). Assim, já que "a situação de agressão injusta que permite a atuação em legítima defesa deve manter uma relação de tempo presente para com a atitude legitimada", a agressão sofrida deve estar acontecendo ou em vias de acontecer (BUSATO, 2017, p. 465), o que não se vislumbra na hipótese levantada.

Noutra senda, caso o homicídio já tenha sido realizado, pode o padre confessor violar o sigilo sacramental, e consequentemente o segredo profissional, denunciando o crime para as autoridades competentes alegando legítima defesa de terceiro? A resposta é, novamente, negativa. Em primeiro lugar, porque a legítima defesa posterior é meramente imaginária; em segundo lugar, porque, conforme já dissertado, a denunciação de crime não é justa causa para a atipicidade da conduta prevista no Art. 154 do Código Penal; e em terceiro lugar, porque, sendo o homicídio já tentado ou consumado, não há mais direito alheio a ser defendido, posto que não haveria como impedir a conduta do agente.

O que pode ocorrer, portanto, no caso de um padre confessor violar o segredo profissional alegando legítima defesa, é "uma percepção equivocada acerca da existência ou atualidade da agressão injusta”, fazendo com que este creia "erroneamente, que se encontra em uma situação de legítima defesa, dando lugar a uma legítima defesa putativa” (BITENCOURT, 2018b, p. 435).

A respeito do estrito cumprimento do dever legal, disposto no Art. 23, III, do Código Penal, é cediço que, assim como no caso do exercício regular do direito, "suas definições ficaram a cargo da doutrina e da jurisprudência”, posto que a lei não forneceu os elementos de natureza 
objetiva, como fez com a legítima defesa e o estado de necessidade (GRECO, 2014, p. 320).

Dessa forma, para sua postulação, "inicialmente, é preciso que haja um dever legal imposto ao agente, dever este que, em geral, é dirigido àqueles que fazem parte da Administração Pública, tais como os policiais e oficias de justiça”. Em segundo lugar, "é necessário que o cumprimento a esse dever se dê nos exatos termos impostos pela lei, não podendo em nada ultrapassá-los" (BITENCOURT, 2018b, p. 369).

Marcelo Jardim Linhares, citado por Nucci, estabelece, dentre outras, as seguintes situações como formas de estrito cumprimento do dever legal: "a comunicação da ocorrência de crime por funcionário público à autoridade, quando dele tenha ciência no exercício das suas funções” e "a denúncia à autoridade feita por médicos, no exercício profissional, da ocorrência de um crime;" (LINHARES, 1983 apud NUCCI, 2017, p. 272). Esses dois exemplos de estrito cumprimento do dever legal dizem respeito a sujeitos com condições especiais, que são obrigadas a manter o segredo profissional: o funcionário público e o médico. Todavia, não se abordou a respeito do sacerdote, que também está incluso no Art. 154 do Código Penal.

Sendo assim, supondo que um indivíduo tenha cometido um homicídio e, imediatamente, tenha procurado o seu confessor, neste caso, o padre confessor pode violar os segredos obtidos na confissão católica embasando-se no estrito cumprimento do dever legal, denunciando à autoridade o cometimento do crime? A resposta também é negativa, pois "sempre que alguém estiver cumprindo, estritamente, um dever imposto pela lei, só poderá estar realizando um comportamento lícito, uma vez que a lei não impõe a ninguém a realização de uma conduta proibida" (BUSATO, 2017, p. 476). E, se violado o segredo profissional, não estará o padre seguindo um dever imposto por lei, ao contrário: estará cometendo um fato típico, ilícito e culpável. Assim, a transgressão do segredo profissional obtido através da confissão sacramental não figura, também, como hipótese de estrito cumprimento do dever legal, persistindo sua inviolabilidade.

Por último, tem-se o exercício regular de direito. Este diferenciase do estrito cumprimento do dever legal pelo fato de o primeiro ser uma obrigação, e o segundo, uma faculdade. Ou seja, "no estrito cumprimento 
do dever há uma norma cogente determinando que o sujeito atue. No exercício regular de um direito há uma norma permissiva, dando possibilidade ao sujeito de atuar" (BUSATO, 2017, p. 479).

Dentre os diversos casos típicos, Marcelo Jardim Linhares cita como hipótese da referida excludente de ilicitude "a divulgação de segredo, ainda que prejudicial, feita com justa causa” (LINHARES, 1983 apud NUCCI, 2017, p. 273).

Causa intensas dúvidas a discussão sobre o que seria uma justa causa que tem o condão de excluir a antijuridicidade da violação de segredo profissional, e quais exemplos práticos para tal, esforço da doutrina penal pátria.

Conforme Fernando Capez (2017, p. 418), “o direito ao sigilo profissional não é absoluto, devendo ceder em face de interesses jurídicos maiores". Prosseguindo, o autor cita como exemplos a comunicação, do advogado às autoridades, de um crime cometido por alguém, a fim de inocentar terceiro, hipótese de estado de necessidade; quando a norma impuser revelação de segredo, como o art. 269 do Código Penal, que obriga o médico a comunicar a autoridade uma moléstia contagiosa, caso de estrito cumprimento do dever legal; e, por último "quando houver consentimento do titular do segredo, o que ocorre quando, por exemplo, o titular do segredo permite a revelação deste pelo profissional em depoimento em juízo” (CAPEZ, 2017, p. 418).

Para Bitencourt (2018a, p. 551), "a justa causa, que torna atípica a conduta, deve ser legal, isto é, deve encontrar fundamento direto ou indireto em norma jurídica", encerrando que "nosso Código Penal filiase à orientação que dá proteção absoluta ao segredo profissional”, em raciocínio contrário ao de Fernando Capez.

Segundo Cunha (2016, p. 241), “estará configurada justa causa sempre que o interesse público se sobrepuser ao profissional”. Para Marco Antônio de Barros (1996, p. 21), "a justa causa identifica-se com o justo impedimento de manter o sigilo, ou com a existência da necessidade de confidência, ela só pode ser aquilatada no caso concreto", incluindo-se obrigatoriamente, neste rol, as excludentes de ilicitude.

Para Souza e Japiassú (2018, p. 649), “entende-se que há justa causa quando o advogado, médico, psicólogo, sacerdote etc., é comunicado da intenção do indivíduo de perpetrar uma ação delituosa contra 
terceiro", argumento contrastado anteriormente, com a explanação das quatro excludentes de ilicitude nos exemplos em questão.

Nessa perspectiva, observa-se que o principal exemplo, citado pela doutrina, de justa causa para a revelação do segredo, é o consentimento do seu titular, "em face da disponibilidade do bem jurídico protegido", pois, caso não haja interesse em preservar o sigilo do fato, por parte do titular, uma eventual revelação pelo confidente não configura a violação do sigilo profissional (PRADO; CARVALHO; CARVALHO, 2014, p. 859).

A contrario sensu deste raciocínio, que defende o consentimento do ofendido como causa justa para a quebra do segredo profissional, "de ver-se que em certos casos a lei não o admite como justa causa para a revelação" (JESUS, 2014, p. 340), pois “é preciso destacar que há muitas profissões protegidas pelo sigilo, ou seja, estão impedidas legalmente de divulgar o segredo, mesmo que autorizado pelo interessado (como ocorre com médicos e advogados)" (NUCCI, 2017, p. 940), estendendo-se também, segundo este artigo, aos padres.

Aduz Busato que uma das razões fortes para a adoção do ponto de vista que defende o consentimento do ofendido se relaciona com a autonomia da vontade, tema que vem ganhando força na doutrina, embora “essa perspectiva não pode ser assumida como regra geral. Em primeiro lugar, porque se deve filtrar os bens jurídicos entre os disponíveis e os indisponíveis, sendo que para os últimos [...], não cabe a aplicação da regra" (BUSATO, 2017, p. 490).

Assim, para ser legítimo e excluir a ilicitude da conduta, o consentimento do ofendido precisa vir acompanhado dos seguintes requisitos: (i) concordância explícita e capacidade do ofendido; (ii) disponibilidade do bem ou interesse; (iii) consentimento dado antes ou durante a prática da conduta do agente, e revogável a qualquer tempo; e (iv) conhecimento do agente acerca do consentimento do ofendido (NUCCI, 2017, pp. 265 e 267; BITENCOURT, 2018a, p. 553; GRECO, 2014, p. 377). "Ausente um desses requisitos, o consentimento do ofendido não poderá afastar a ilicitude do fato" (GRECO, 2014, p. 152).

Ora, se o consentimento do ofendido diz respeito à disponibilidade do determinado bem jurídico, não parece viável relacionar a referida causa de justificação - que é supralegal - ao caso de violação de fato 
obtido por confissão sacramental, uma vez que a intimidade, invólucro do referido sacramento, é um bem indisponível - com o devido respeito às opiniões contrárias -, assim como a vida, a liberdade, a dignidade, também direitos personalíssimos.

Conforme Greco (2014, p. 377), "se o bem for indisponível, mesmo que o consenciente seja capaz, tal consentimento não será levado em consideração.” Desta forma, sendo a intimidade um bem indisponível, o confidente dela não pode dispor, portanto, não se considera factível a justificativa de o consentimento ofendido figurar como motivo para violação do segredo profissional, no sentido estrito da confissão sacramental ${ }^{22}$.

Em arremate à impossibilidade de o consentimento do ofendido elidir o crime tipificado no Art. 154 para os casos de padres confessores, questiona-se: (i) se a confissão sacramental é um espaço para revelar informações e segredos íntimos, por que alguém abdicaria de sua inviolabilidade, consentindo com a transgressão?; (ii) se o consentimento do ofendido deve ser anterior ou simultâneo à conduta do agente que viola o segredo profissional, porque realizar a confissão, já que supõe-se que o confidente busca o sacramento para que seus fatos íntimos não sejam conhecidos por outro indivíduo se não o sacerdote, que goza de sua confiança?

Esses questionamentos denotam um paradoxo contido na relação entre consentimento do ofendido e violação de sigilo sacramental. Mesmo porque, como dito anteriormente, mesmo que o penitente consinta com a revelação do que foi confessado, o padre católico poderá continuar exercendo seu direito e dever de guardar o sigilo sacramental, o que corrobora o argumento de inviolabilidade do sigilo sacramental, por parte do confidente necessário, independentemente do bem jurídico contraposto.

Nesse sentido, o que diferencia primeiramente o sigilo profissional para os padres e para outros profissionais é o caráter sacramental

22 Na ótica católica, também não se vislumbra a hipótese de consentimento do ofendido para a violação do sigilo sacramental. Cân. 1550, § 2, item $2^{\circ}$. "Consideram incapazes os sacerdotes, no respeitante a tudo quanto conhecem por confissão sacramental, ainda que o penitente peça que o manifestem" (JOÃO PAULO II, 1983, p. 268-269). 
conferido aos primeiros, pois, sendo o Estado laico, este deve proteger as religiões e suas particularidades, não possuindo a prerrogativa de "interferir nas questões internas das religiões, como os valores professados, a forma de professá-los ou sua organização institucional” (NOVELINO, 2016, p. 355).

Outrossim, no que se refere à violação de sigilo sacramental, deve-se ter em mente o peso das convicções religiosas de cada ser humano. Quem busca o padre para confessar-lhe os pecados, fâ-lo por imposição religiosa, vontade própria e finalidade salvística da sua alma e libertação de sua consciência (ALMEIDA, 2015, p. 71).

Noutro aspecto, "o sigilo profissional é exigência fundamental da vida social que deve ser respeitada como princípio de ordem pública, razão pela qual o Poder Judiciário [ou o Legislativo, que emana as leis] não dispõe de força cogente para impor a sua revelação" (BITENCOURT, 2018a, p. 550).

Ademais, além do caráter jurídico da obrigação de o padre não violar os segredos ouvidos na confissão, há uma intensa ligação de seu ministério de confessor com uma função entendida pela Igreja Católica como determinada por Jesus, fazendo com que a transgressão desse ofício seja um desrespeito não só às normas jurídicas e católicas, mas também ao que é divino, o que aumenta o caráter delicado e absoluto do sigilo sacramental enquanto segredo profissional.

\section{Considerações Finais}

Por muito tempo, o Direito esteve submetido às regras religiosas, e mesmo com uma mudança de paradigmas, o Estado, agora laico, precisou garantir a proteção das religiões e suas especificidades. É nesta perspectiva que desponta o sacramento católico da confissão, fenômeno com reflexos jurídicos, dado seu caráter absoluto, assim considerado pelas normas católicas, ou contendo exceções, na ótica da doutrina pátria e nas locuções finais dos arts. 154 do Código Penal e 207 do Código de Processo Penal.

Nesse sentido, sendo a confissão de pecados uma expressão significativa de confiança do penitente no sigilo sacramental, invólucro 
de seus aspectos mais íntimos, resta inconteste o direito e o dever de o padre resguardar a inviolabilidade dos fatos obtidos através do dito sacramento, para não comprometer a intimidade do confidente - por mais que este consinta com a relevação da confissão -, bem como não transgredir as normas impostas pelo ordenamento católico em razão do ministério sacerdotal.

Nesse diapasão, o artigo trouxe como problema o seguinte questionamento: o segredo profissional obtido pelo padre através da confissão, permanece inviolável, independentemente da alegação de justa causa, como excludente de ilicitude ou consentimento do penitente?

Entendeu o estudo que sim, pois: não obstante a doutrina penal pátria tenha elencado hipóteses de justa causa para sua violação, e mesmo que o penitente consinta com a revelação do informe dito em confissão, os padres confessores devem obediência à doutrina do seu ministério sacerdotal, às autoridades competentes do ordenamento católico e jurídico e também ao divino, vez que considera-se o sacramento da confissão como um ensinamento deixado pelo próprio Jesus.

À guisa de conclusão, e sem a pretensão de exaurir a discussão temática, considera-se este artigo como uma tentativa de elucidar acerca o dever de o padre não violar o segredo profissional, independentemente do bem jurídico contraposto ou da justificativa alegada, trazendo, para tal, uma visão multidisciplinar sobre o assunto.

\section{REFERÊNCIAS}

AZEVEDO, Catarina Susana Oliveira e Sousa Esteves de. Segredo Religioso. O Múnus do Silêncio. Dissertação de Mestrado (Especialização em Ciências JurídicoForenses). Faculdade de Direito da Universidade de Coimbra, 2015. Disponível em: $<$ https://bit.ly/3aihO2x >.

BARROS, Marco Antônio de. Sigilo profissional: reflexos da violação no âmbito das provas ilícitas. Justitia, São Paulo, v. 58, n. 175, p. 17-33, jul./set. 1996. Disponível em: < http://www.revistajustitia.com.br/revistas/6ca278.pdf >.

BITENCOURT, Cezar Roberto. Tratado de direito penal: parte especial 2: crimes contra a pessoa. 18. ed. São Paulo: Saraiva Educação, 2018a.

BITENCOURT, Cezar Roberto. Tratado de direito penal: parte geral 1. 24. ed. São Paulo: Saraiva Educação, 2018b. 
BUSATO, Paulo César. Direito penal: parte geral, v. 1. 3. ed. rev., atual. e ampl. São Paulo: Atlas, 2017.

CAPEZ, Fernando. Curso de direito penal, volume 1, parte geral. 22. ed. São Paulo: Saraiva Educação, 2018.

CAPEZ, Fernando. Curso de direito penal, volume 2, parte especial: arts. 121 a 212. 17. ed. São Paulo: Saraiva, 2017.

CESCA, Brenno Gimenes; ORZARI, Octavio Augusto da Silva. Prova Penal e Segredo Profissional. Revista da Faculdade de Direito, Universidade São Paulo, v. 111, p. 555 - 586, jan./dez. 2016. Disponível em: < http://www.revistas.usp.br/ rfdusp/article/view/133529/129537 >.

CUNHA, Rogério Sanches. Manual de direito penal: parte especial (arts. 121 ao 361) - 8. ed. rev., ampl. e atual. - Salvador: JusPODIVM, 2016.

CUNHA JÚNIOR, Dirley da. Curso de direito constitucional. 8. ed. rev., ampl. e atual. JusPODIVM, 2014.

DESTÉFANI, Frei Benvindo. O Santo Sacramento da Penitência. 2 ed., rev. e aum. Petrópolis: Editora Vozes, 1940.

DUARTE, Pe. Luiz Miguel. O Sacramento da Reconciliação: orientações práticas para uma boa confissão. 1. ed. São Paulo: PAULUS, 2008.

FERRAZ, Sérgio Valladão. Curso de direito constitucional: teoria e questões. 2. ed. Rio de Janeiro: Elsevier, 2006.

GRECO, Rogério. Curso de Direito Penal. 16. ed. Rio de Janeiro: Impetus, 2014.

GRECO, Rogério. Curso Direito Penal: parte especial / volume II: introdução à teoria geral da parte especial: crimes contra a pessoa. 6. ed. Niterói: Impetus, 2009.

JESUS, Damásio de. Direito penal, $2^{\circ}$ volume: parte especial; Crimes contra a pessoa a crimes contra o patrimônio. 34. ed. São Paulo: Saraiva, 2014.

JOÃO PAULO II. Catecismo da Igreja Católica. Vaticano, 1992. Disponível em: < http://www.vatican.va/archive/ccc/index_po.htm >.

JOÃO PAULO II. Código de Direito Canônico. 4. ed. rev. Versão portuguesa: Conferência Episcopal Portuguesa, Lisboa, 1983. Disponível em: < http://www.vatican. va/archive/cod-iuris-canonici/portuguese/codex-iuris-canonici_po.pdf $>$.

LOPES, José Joaquim Almeida. O delito canónico e civil de violaçao do sigilo sacramental. Revista Española de Derecho Canónico, vol. 63, nº 160, 2006, págs. 47-123. Disponível em: < https://summa.upsa.es/details.vm?q=id:0000029579 >. 
MACIEL, José Fábio Rodrigues. Código de Direito Canônico. Disponível em: < http:// www.cartaforense.com.br/conteudo/colunas/codigo-de-direito-canonico/683 >.

MORALES, Ícaro Lopes. A influência do catolicismo no estado laico. Monografia (Mestrado em Direito). Centro Universitário Toledo, Araçatuba-SP, 2018. Disponível em: < https://servicos.toledo.br/repositorio/handle/7574/1731 >.

NADER, Paulo. Introdução ao estudo do direito. 38. ed. Rio de Janeiro: Forense, 2016.

NEVES, Daniel Amorim Assumpção. Manual de direito processual civil. 10. ed. rev. atual. São Paulo: JUSPODIVM, 2018.

NOVELINO, Marcelo. Curso de direito constitucional. 11. ed. rev., ampl. e atual. Salvador: Ed. JusPodivm, 2016.

NUCCI, Guilherme de Souza. Código de processo penal comentado. 11. ed. rev., atual. e ampl. São Paulo: Editora Revista dos Tribunais, 2012.

NUCCI, Guilherme de Souza. Código penal comentado. 18. ed. rev., atual. e ampl. Rio de Janeiro: Forense, 2017.

PACELLI, Eugênio. Curso de processo penal. 22. ed. rev., atual. e ampl. São Paulo: Atlas, 2018.

PRADO, Luiz Regis. Curso de direito penal brasileiro, volume 2: parte especial: arts. 121 a 249. 7. ed. rev., atual. e ampl. São Paulo: Editora Revista dos Tribunais, 2008.

PRADO, Luiz Regis; CARVALHO, Érika Mendes; CARVALHO, Gisele Mendes. Curso de direito penal brasileiro. 13. ed. rev. atual. e ampl. São Paulo: Editora Revista dos Tribunais, 2014.

RANGEL, Paulo. Direito processual penal. 23. ed. São Paulo: Atlas, 2015.

SOUZA, Artur de Brito Gueiros; JAPIASSÚ, Carlos Eduardo Adriano. Direito penal: volume único. São Paulo: Atlas, 2018. 


\section{Informações adicionais e declarações dos autores (integridade científica)}

Declaração de conflito de interesses (conflict of interest declaration): os autores confirmam que não há conflitos de interesse na realização das pesquisas expostas e na redação deste artigo.

Declaração de autoria e especificação das contribuições (declaration of authorship): todas e somente as pessoas que atendem os requisitos de autoria deste artigo estão listadas como autores; todos os coautores se responsabilizam integralmente por este trabalho em sua totalidade.

- Samyle Regina Matos Oliveira: projeto e esboço inicial (conceptualization), desenvolvimento da metodologia (methodology), coleta e análise de dados (data curation), levantamento bibliográfico (investigation), revisão bibliográfica (investigation), redação (writing - original draft), participação ativa nas discussões dos resultados (validation), revisão crítica com contribuições substanciais (writing - review and editing), aprovação da versão final.

- Thyerrí José Cruz Silva: projeto e esboço inicial (conceptualization), desenvolvimento da metodologia (methodology), coleta e análise de dados (data curation), levantamento bibliográfico (investigation), revisão bibliográfica (investigation), redação (writing - original draft), participação ativa nas discussões dos resultados (validation), revisão crítica com contribuições substanciais (writing - review and editing), aprovação da versão final.

- Luiz Fernando Kazmierczak: revisão bibliográfica (investigation), revisão crítica com contribuições substanciais (writing - review and editing), aprovação da versão final.

Declaração de ineditismo e originalidade (declaration of originality): os autores asseguram que o texto aqui publicado não foi divulgado anteriormente em outro meio e que futura republicação somente se realizará com a indicação expressa da referência desta publicação original; também atestam que não há plágio de terceiros ou autoplágio. 
Dados do processo editorial

(http://www.ibraspp.com.br/revista/index.php/RBDPP/about/editorialPolicies)

- Recebido em: 06/10/2019

- Deslocamento ao V6N1 e aviso autores:

Equipe editorial envolvida 19/10/2019

- Controle preliminar e verificação de plágio: 09/12/2019

- Editor-chefe: 1 (VGV)

- Editor-assistente: 1 (CRG)

- Revisores: 2

- Avaliação 1: 22/12/2019

- Avaliação 2: 26/12/2019

- Decisão editorial preliminar: 15/03/2020

- Deslocamento ao V6N2 e aviso autores: 15/03/2020

- Retorno rodada de correções: 27/03/2020

- Decisão editorial final: 05/04/2020

\section{COMO CITAR ESTE ARTIGO:}

OLIVEIRA, Samyle Regina Matos; SILVA, Thyerrí José Cruz; KAZMIERCZAK, Luiz Fernando. Quebra do Segredo Profissional por padres católicos: (im) possibilidade de violação do sigilo sacramental. Revista Brasileira de Direito Processual Penal, Porto Alegre, vol. 6, n. 2, p. 1025-1055, mai./ago. 2020. https://doi.org/10.22197/rbdpp.v6i2.286

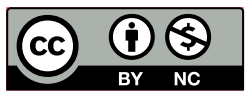

Esta obra está licenciada com uma Licença Creative Commons Atribuição-NãoComercial 4.0 Internacional. 